\title{
Media Relations in the PR Structure of the Judiciary
}

\author{
Olga Vladimirovna Tretyakova ${ }^{1 *}$, Olga Nikolaevna Ivanishcheva ${ }^{2}$, Anna Vladimirovna Gushchina ${ }^{2}$, Ekaterina Vla- \\ dimirovna Tretiakovich ${ }^{2}$, Viktoria Gennadievna Piksendeeva ${ }^{2}$ \\ ${ }^{1}$ Northern (Arctic) Federal University named after M.V. Lomonosov, Severnaya Dvina Emb., 17, 163002, Arkhangelsk, Russia \\ ${ }^{2}$ Murmansk Arctic State University, Captain Egorov St., 15, Murmansk, 183038, Russia \\ *Corresponding authorE-mail: tretyakova.o.v@inbox.ru
}

\begin{abstract}
The article analyzes the liaison between judges and journalists as part of the information policy of the judiciary. It is shown herein that the restriction of access to judicial information, the shortcomings in the operation of the communication and information structures of the courts hinder the maintenance of the authority of justice in society. It is proved that the press service is responsible for public relations and media relations. As a result of this approach, the press services created by the courts are unable to participate efficiently in the interaction of the media and the judiciary, and the contacts between journalists and judges are minimized. The data of surveys of judges, journalists and the population of the Arkhangelsk Region are presented with the purpose to reveal if information about judicial proceedings is in demand in society and how open the judiciary is. It is shown that the majority of judges of district and city courts consider that the information on the operation of courts is in demand by society to a sufficient degree. However, at the same time, journalists face the problems of access to information, although the population considers the information on the operation of the judiciary in demand.
\end{abstract}

Keywords: Access to court information; Image of the judiciary; Information policy; Journalism.

\section{Introduction}

The information policy of the judiciary includes the implementation of important principles of justice - openness and publicity. The level of confidence in judges and respect for the court on the part of society depends on the publicity of the judiciary. The access of citizens to judicial information and the possibility of its wide discussion are the essential elements of the justice of the court, by virtue of the fact that in the atmosphere of publicity the probability of miscarriage of justice or assignment of a disproportionately severe punishment to a guilty person is significantly reduced, which also has a direct bearing on the authority of justice. The requirement of transparency (openness) of justice $[1,2,3]$ was formulated as one of the representations of natural fair justice back in the 17th century in the UK: "It is not enough to know that there is justice, it is necessary to see that it is being implemented". This requirement is contained in many international documents. For example, the European Convention for the Protection of Human Rights and Fundamental Freedoms and the International Covenant on Civil and Political Rights state that everyone has the right to a fair and public hearing within a reasonable time by an independent and impartial tribunal.

In Russia, the issue of court openness was raised in the second half of the 19th century, during the period of the judicial reform of Alexander II. In 1864, new Judicial Charters were approved and a system of judicial institutions independent from the administrative authority and police department was created; there appeared magistrates' courts and a jury. The Charter of Criminal Proceedings determined that the judge "hears the cases verbally and publicly". Due to the press, the judicial reform received great public support. Grigory Dzhanshiev, Russian jurist, attorney at law and historian, who in 1876-1878 worked as a court reporter for the newspapers Moskovskie Vedomosti and Russkie Vedomosti, cited in his study the views of progressive publicists of the time: "Better one or two scandalous cases will be announced than dozens, hundreds of cases will be deprived of publicity" [4].

However, as early as 1887,620 articles of the Statute of Criminal Procedure were amended: "The unauthorized persons are admitted to the court sessions in a number corresponding to the Court's premises and not hampering the proper course of judicial action". The Minister of Justice explained: public consideration of judicial proceedings "could serve to excite the minds and disturb the order". The range of cases that were considered by the jury was also limited. The independence of the court gradually left no trace. This is very reminiscent of what happened in Russia in the 1990s: the introduction of the institutions of magistrates and jurors, the declaration of transparency of justice, the creation of the concept of the information policy of the judiciary, publicity and its subsequent limitations.

Thus, in the 19th and 20th centuries, the views on the openness of the judiciary and on the interaction of judges and journalists changed.

Formally, in modern Russia, openness and transparency, along with independence and credibility, are mandatory points in assessing the work of courts and even individual judges $[5,6]$. Article 123 of the Constitution of the Russian Federation establishes that proceedings in all courts are open, and only in cases provided for by the federal law, closed proceedings are allowed.

The purpose of this article is to analyze the organization of interaction between judges and journalists as part of the information policy of the judiciary of the Russian Federation.

\section{Methods}

The methods used in the article were as follows: a survey, an expert survey, an analysis of documents. A survey of 50 judges of 
regional and city courts of the Arkhangelsk Region of the Russian Federation, 10 journalists of Arkhangelsk newspapers and 70 residents of Arkhangelsk was presented herein.

\section{Results}

Mass media are one of the tools for implementation of the right of citizens to obtain information about the operation of the authorities $[7,8,9,10,11]$, especially in modern era, taking into account the subjectivity of journalists' judgments [12]. The provisions of Article 38 of the Law of the Russian Federation "On Mass Media" establish the right of citizens to obtain reliable information promptly through mass media (hereinafter - the media) about the operation of state bodies and organizations, public associations, their officials. This can be seen as the requirement of information transparency of social institutions, and the appeal to the duty of the press to inform the society about their activities.

These provisions are implemented in public bodies, organizations of various forms of ownership and public associations through public relations services, or public affairs departments, whose structure includes press secretaries and press services, i.e. media relations divisions. Media relations are a part of public relations (hereinafter referred to as PR), which is "responsible" for delivering information to the target audience through the media $[13,14]$. The liaison with journalists places strong demands on specialists in media relations:

1) to know the functions and principles of operation of the media: the deadlines, the peculiarities of the perception of the information published on the newspaper page, the timing of the preparation of TV stories, the format of radio broadcasts, the beginning of the editing of the latest news, etc.;

2) to get acquainted with journalists, both by correspondence and in person. The acquaintance by correspondence means the acquaintance with their publications, stories, creative preferences. Personal communication is important for creating benevolent relationships and understanding what information is most interesting to them;

3) to become a reliable source of information, to earn the confidence of journalists, providing complete and reliable information; 4) to understand that journalists need extraordinary, exclusive information, often they are interested only in scandals and negative information, so it is important to learn to neutralize and optimize the information interaction;

5) to be permanently accessible not only to provide the media with reliable information but also to help journalists obtain a comment from the management of the organization;

6) to be experts in their field of operation. The demonstration of competence, a broad outlook, the ability to analyze different situations - these are the invaluable resource of specialists, which are used by the media [15, pp. 62-68].

To collaborate efficiently with media representatives, to establish closer business contacts (which also means a broad coverage of the agency's activities in the media), media relations' specialists organize press conferences, press tours, excursions to objects, doors open days, festive events, presence of journalists at the planned events (meetings, conferences), etc.

The concept of the information policy of the judiciary, approved by the decision of the Council of Judges of the Russian Federation in November 2001, provided for the development of an information infrastructure, namely, communication and information units responsible for interaction with the public and the media. It was intended to establish press services of higher courts, the institution of staff press-secretaries of arbitration courts, regional courts of general jurisdiction and administrations of the Judicial Department as independent, adequately staffed structural units. The main goal of these structures is to facilitate the access to the media representatives for obtaining the information on the operation of courts that create the increased public interest, and to raise the level of mutual understanding between judges and journalists
[16].

However, in addition to this, the press services and press secretaries of the judiciary are also in charge of the following tasks: monitoring of the media; study of public opinion on the work of courts; accreditation of journalists; organization of media coverage of operation of courts, including through the creation and maintenance of permanent headings and thematic programs in the media; preparation and dissemination in the media of court chairmen speeches, official materials of the judicial bodies and the bodies of the judicial community; prompt response to publications in the media related to the activities of the judiciary; preparation of analytical and reference information materials, organization of editorial and publishing activities.

Moreover, press services are in charge for holding conferences with the representatives of the media with the participation of the leaders of the judiciary; the organization of creative competitions for the best coverage of the courts, the establishment of prizes for journalists and even for the creation of their own information resources and the judiciary media.

\section{Discussion}

In practice, press services as independent communicative and informational units are established only in the Constitutional and Supreme Courts and in the Supreme Arbitration Court, while at the regional level the information support for the activities of courts is assigned to the administrations of the Judicial Department under the Supreme Court of the Russian Federation. Subsequently, the chairpersons of the courts began to find opportunities for employment (usually for some technical position) of press secretaries able to prepare press releases for the regional courts.

The management of the regional administrations of the Judicial Department in each city and district court appoints a person responsible for interaction with the media from among the staff of the court apparatus, judicial offices or secretaries of court sessions, most often not meeting the requirements for the press officer, who does not understand what information and why the media need. There is no doubt that they are not able to carry out the numerous tasks assigned to them (listed above). They understand their functions in their own way: 1) to advertise the court in the media, and to avoid anti-advertising by restricting the presence of journalists in the courts, 2) to assist the reporters in gaining the access to judicial proceedings and judges, 3 ) to show no initiative, responding under absolute necessity only to the requests of the media this understanding is most often encountered.

Due to a direct indication of the Law "On Mass Media" (Article 47 ), a journalist is entitled to review the materials of judicial proceedings that do not constitute a secret protected by law. However, in procedural laws, a journalist is not identified as a person entitled to review the materials of judicial proceedings. At the same time, the procedural codes do not contain an exhaustive list of persons entitled to review the materials of judicial proceedings. Thus, it seems obvious that the inclusion of a journalist in this list does not violate the provisions of the procedural law. Moreover, it is established by the Recommendation of the Committee of Ministers of the Council of Europe to the participating Countries to provide information on the criminal proceedings through the media, adopted by the Committee of Ministers on July 10, 2003, that "journalists should be allowed, without any discrimination, to produce or receive the copies of the sentences, imposed openly. They should be able to disseminate these sentences or bring them to the attention of the public" [17].

However, there is no mention in the instructions for the Office of the Judicial Department of journalists as the persons entitled to review the materials of judicial proceedings. Therefore, when a journalist requests from the court office a copy of the court decision to get acquainted with, the employees of the office reject such a request on the grounds that a journalist is not a party to the proceedings and not an employee of the Ministry of Internal Affairs 
or the prosecutor's office, and the journalists do not appear as the recipients of information in the Instruction.

The creation of media relations' departments in the administrations of the Judicial Department - a bureaucratic structure that deals with the material, technical, personnel and organizational support of courts - is hardly sound from the point of view of the competent organization of media relations. The press service employees should be able to contact judges closely, to provide the journalists with the access to courtrooms and court materials, to inform regularly the media about the trials and schedules of hearings, instead of drawing up instructions, regulations and rules of conduct.

In 2011, the Council of Judges of the Arkhangelsk Region approved the "Recommendations on the Procedure for Providing Information on Judicial Proceedings in the Media" prepared by the press secretary of the Judicial Department. The "algorithm for coordinating the issue of acknowledgement of a representative of the media with the proceedings" included in the recommendation consists of several points: upon receipt of a written request from the editorial office, it is required to "notify the parties to the proceedings through telephone communication"; "given the verbal consent of the said parties, invite them to the court to register the consent or to send it by post or facsimile"; notify the representative of the media about the date, time and place of acknowledgement with the proceedings and warn about the requirement to have a written petition of the editorial office, which guarantees the nondisclosure of personal data available in the proceedings; conclude a personal data non-disclosure agreement with a media representative.

The authors of this "coordination algorithm" seem to have done everything to ensure that journalists never in their lives have a desire to learn about any judicial matter. And this is also hopeless: it is unrealistic to get the consent of both parties to prepare a publication on the judicial proceedings (at best, one of the parties may be interested in this). Only people who have never worked in the media can ask a journalist not only to sign a personal data nondisclosure agreement but also to obtain a written petition from the editorial office. All this completely paralyzes the work of judicial journalists and demonstrates the low level of legal culture of the authors of the document.

The court is an organ of public authority, and every person who applied to the court for the resolution of his private dispute voluntarily leaves the private for the public; journalists are not required to ask for any written consent to publish the materials of judicial proceedings. And all the responsibility for personal data disclosure lies with the author of the future material, rather than with the officials from the Judicial Department. In caring for the protection of "privacy", it is often forgotten that the personal data of the participants in the proceeding become public due to the publicity of the process and the possibility of being present at an open trial to all who wish. There is only the secret of the consultation room in court; all other information should be open.

Moreover, the law on access to court information states that if the information requested is posted on official websites of the courts on the Internet, the courts are entitled not to provide such information to journalists, indicating the electronic address of the official site and the page on which this information is posted instead. And the staff members of the courts increasingly use this, despite the fact that it is often impossible to gather from the information on the Internet resource any details that have influenced the resulting decision. The informatization of the courts, designed to increase the access to judicial information, does not yet meet expectations.

The Federal Law of the Russian Federation "On Providing Access to Information on the Operation of Courts in the Russian Federation" that entered into force in 2010 stipulates that full texts of all decisions (resolutions, sentences) and the information on the appeals and their results should be posted on the websites of the courts. However, the law does not specify the terms for posting judicial acts on the websites after their entry into force (in a day or, perhaps, in a year?); moreover, there are many restrictions that prevent the publication of full texts of judicial acts.

According to the experts, the "Internetization" of the courts revealed a fundamental contradiction between the two legal principles - openness of justice and protection of personal data [18] The principle of "privacy" - protection of the privacy of citizens and their personal data - did not play such an important role in the proceedings through to the Internet. The Internet has made the publicity of judicial decisions unlimited. Moreover, any restrictions promoted under the guise of "privacy" are in conflict with the more general principle of openness and publicity of justice. The Law of the Russian Federation "On Personal Data" (2006) originally stated that it would not apply to the relations arising when the information was provided by the authorized bodies on the operation of courts, but numerous amendments were made to both competing laws, and all of them subsequently turned out to be against publicity.

The first version of the law on access to judicial information contained the rule that, in order to ensure the safety of litigants, most personal data should be excluded from the texts, except for the names and initials of the judges who considered the case, as well as the prosecutor and lawyer who participated in it. Later, this rule was amended to include the names and the initials of the plaintiff, defendant, convicted or acquitted, as well as the clerk of the court session. The initials or pseudonyms that prevent the identification of the citizens identify the suspected and accused persons, victims, witnesses, interpreters and experts, experts, applicants and other interested persons. The experts believe that the transparency of justice can be reduced to a minimum, "namely, to the stories about the punishment of the nameless street criminals" [19].

Moreover, there is a logical question: the texts announced in the court in an open judicial session differ very much from watereddown decisions and sentences published on the website. Simultaneously with the electronic ersatz document, the hard copy of a judicial act, stored in the archives of the court, will contain the full information voiced during the public hearing. Is it possible in this case to speak about the identity of the electronic document and the source? Is the impersonal information accurate, can a judicial reporter refer to it as a source? It turns out that a journalist cannot work with such a "bank of judicial decisions". In order for the press not to be accused of unfoundedness and partiality, the original sources themselves should be open, full-text and not subject to additional censorship

The websites of the courts with a uniform design and almost identical structure are created within the framework of a comprehensive electronic database of court decisions - the State Automated System (hereinafter - SAS Justice). However, only about $50 \%$ of decisions on criminal cases, $10 \%$ on civil and administrative cases are published on the websites, and then at the expense of the highest courts that are most open. In the regional, city and district courts, there are very few specialists with the technical education necessary for website administration. Approximately every 20th Russian court ignores the law - it does not publish any judicial acts, referring to the protection of personal data. Very often, the names of organizations, products and brands, dates are removed from the decisions, the links to the web pages of the state bodies, etc. are unstable, often the section "Judicial Acts" is simply closed. The search for information on the activities of the courts of SAS Justice is difficult even for specialists (in this respect, private sites, for example, RosPravosudie, Pravo.ru, and the information agency "Judicial Decisions of the Russian Federation") are advantageous. In the Arkhangelsk Region in 2018, judges, journalists and the public were interviewed by the authors in order to determine whether the information on judicial proceedings was in demand in society, and how open the judiciary was.

The majority $(75 \%)$ of the surveyed judges of district and city courts consider that the information on the operation of courts is in demand by society sufficiently. Half of the respondents believe that the adoption of the Federal Law "On Providing Access to Information on the Operation of Courts in the Russian Federation" 
has contributed to an increase in the openness of the judiciary, and at present, the courts are open to a sufficient degree. Another $40 \%$ of the judges answered that the courts were open to a high degree, and only $10 \%$ mentioned the closedness of the judiciary. Despite the high estimation of the demand for judicial information and the openness of courts, $68 \%$ of the interviewed judges believe that some topics should be closed for the media: the rights of minors, protection of privacy and personal data.

The expert poll of the journalists showed that not all editor offices had a specialist who was constantly engaged in legal or judicial matters, and the journalists, as a rule, did this seldom, using the information from the news feed of the courts. Sometimes the journalists encountered the problems with access to information: $50 \%$ of respondents faced the fact that they were not allowed to enter the courtroom, $40 \%$ were faced with a ban on audio and video recording. Regarding the cooperation with the courts' press services, $60 \%$ of respondents noted that they constantly addressed them, $30 \%$ - often, and only $10 \%$ rarely asked them for help.

According to the results of the population survey, $48 \%$ of respondents considered information on the activities of the judiciary to be in demand sufficiently, but the residents of the region were not informed about it well enough (27\% of respondents), and $38 \%$ admitted that they knew practically nothing about the operation of courts in the region. At the same time, $44 \%$ of respondents were interested in the information about the protection of their rights and legitimate interests, they especially needed information about when to apply to the court.

\section{Conclusion}

The judiciary community of the Arkhangelsk Region considers the operation of the press service as an activity aimed at forming a favorable public opinion on the operation of courts, increasing the authority of the judiciary and the prestige of the profession of the judge [20, p. 31]. That is, the PR function is assigned to the press service through the creation of its own information product (telecast or website on the Internet), as well as through annual competitions for journalists, editorial and publishing activities, placement of the judicial acts in the ConsultantPlus system. At the same time, the press service employees are not relieved from media relations either by constant interaction with the media: the accreditation of journalists, organization of press conferences and briefings, mailing of press releases, etc.

As a result of this approach, the press services created by the courts cannot efficiently participate in the interaction of the media and the judiciary, and the contacts of journalists with judges are minimized. As a rule, dosed, filtered information about trials contained in press releases or the words of the press secretary of the court is offered to the journalists. The refusal to provide the journalists with complete and reliable information, the shortcomings in the activities of communicative and informational structures of the judiciary lead to dissemination in the press of the information, rumors and conjectures that do not correspond to reality and impede the maintenance of the authority of justice in society.

\section{References}

[1] Abrosimova EB (2001), Transparentnost pravosudiya [Transparency of Justice]. Sudebnye novosti. Obozrenie, 1-2.

[2] Seriy VV (2011), Imidzh sudebnoi vlasti v sovremennoi Rossii [The Image of the Judiciary in Modern Russia]. Obozrevatel 8(259), 79-84.

[3] Supataev MA (2010), Svoboda i spravedlivost v rossiiskom prave (tsivilizatsionnyi aspekt) [Freedom and Justice in the Russian Law (Civilizational Aspect)]. Gosudarstvo i pravo 4, 5-11.

[4] Dzhanshiev GA (2008), Epokha velikikh reform [The Age of Great Reforms]. Moscow: Territoriya buduschego, 1 .

[5] Verkhovskaya AI (2010), Sredstva massovoi informatsii kak institut grazhdanskogo obshchestva [Mass Media as an Institution of Civil Society]. In Zhurnalistika v 2009 godu: Transformatsiya sistem SMI $v$ sovremennom mire. Sbornik materialov Mezhdunarodnoi nauchno-prakticheskoi konferentsii [Journalism in 2009: Transformation of Media Systems in the Modern World. Collection of Materials of the International Scientific and Practical Conference]. Moscow: Department of Journalism of the Moscow State University.

[6] Konovalov AO (2013), Problemy realizatsii konstitutsionnogo prava na sudebnuyu zashchitu prava na dostup $\mathrm{k}$ informatsii o deyatel'nosti sudov (na materialakh Novosibirskoi oblasti) [Problems of the Implementation of the Constitutional Right to Judicial Protection of the Right to Access the Information on Operation of Courts (Based on the Materials of the Novosibirsk Region)]. Voprosy sovremennoi yurisprudentsii 26, 71-79.

[7] Bobrov DA (2014), Sostoyanie i perspektivy vzaimodeistviya organov sudebnoi vlasti so SMI pri realizatsii dostupa $\mathrm{k}$ informatsii o deyatelnosti sudov [The State and Prospects of Interaction of Judicial Authorities with the Media in the Implementation of Access to Information on the Activities of the Courts]. Uchenye zapiski Kazanskogo universiteta. Seriya: Gumanitarnye nauki 156(4), 189-199.

[8] Dankova NS (2016), Reprezentatsiya sudebnoi vlasti v diskurse rossiiskikh i angliiskikh pechatnykh SMI: strategiya aktivatsiya [Representation of the Judiciary in the Discourse of Russian and English Print Media: Strategy Activation]. Izvestiya Saratovskogo Universiteta. Novaya seriya. Seriya: Filologiya. Zhurnalistika, 16(4), 452-459.

[9] Sidorov VA (2010), Aksiologiya zhurnalistiki informatsionnoi epokhi: ponimanie sotsialnoi missii zhurnalistiki [Axiology of Journalism of the Information Age: Understanding of the Social Mission of Journalism]. In Zhirkov GV \& Sidorov VA (Eds), Materialy Vserossiiskoi nauchno-prakticheskoi konferentsii "Tsennosti zhurnalistiki $i$ dostoinstvo zhurnalista (aksiologiya zhurnalistiki)" [Proceedings of the All-Russian Scientific-Practical Conference "Values of Journalism and the Dignity of a Journalist (Axiology of Journalism)"]. St. Petersburg.

[10] Tretyakova OV (2008), Pravovaya zhurnalistika: Uchebnoe posobie [Legal Journalism: A Textbook]. Arkhangelsk: Pomor University.

[11] Gritsenko EV, Babelyuk EG \& Proskuryakova MI (2016), The Right of Access to Information on the Public Administration in Russia and Germany: Constitutional and Legislative Framework. Journal of Siberian Federal University. Humanities \& Social Humanities 9(9), 2202-2222.

[12] Carlsson M (2018). Automating Judgment? Algorithmic Judgment, News Knowledge, and Journalistic Professionalism. New Media and Society 20(5), 1755-1772.

[13] Nazaykin AN (2009), Organizatsiya media relations [Organization of Media Relations]. MediaScope 4

[14] Financial Times, Definition of Media Relations. http://lexicon.ft.com/Term?term=media-relations

[15] Veksler AF, Svyazi s obshchestvennostyu dlya biznesa [Public Relations for Business]. Nizhny Novgorod: PR-Expert, 2001.

[16] $O$ kontseptsii informatsionnoi politiki sudebnoi sistemy $R F$ : postanovlenie Soveta Sudei RF ot 16.11.2001g. No. 60 [On the Concept of Information Policy of the Judiciary of the Russian Federation: Resolution of the Council of Judges of the Russian Federation No. 60].

[17] Yuridicheskaya Rossiya. Federalnyi pravovoi portal [Legal Russia. Federal Legal Portal]. http://www.law.edu.ru/article/article.asp?articleID=1190659

[18] Nikitinsky L, Robota Netupskogo - pod sud [Bring to Justice Robot Netupsky!]. Novaya gazeta, 8 July 2016.

[19] The Comment of the Media Rights Center of the Faculty of Journalism of the Moscow State University, Bolshe glasnosti v rabote sudov - no nenamnogo i ne seichas. [More Publicity in the Work of the Courts - but Not Much and Not Now]. The site of the Center for Journalism in Extreme Situations. News feed, 2009. http://www.lenta.cjes.ru/?m=1\&y=2009\&lang=rus\&nid=592

[20] Bunkov VG (2003), Sudebnaya vlast i sredstva massovoi informatsii: problema vzaimodeistviya [Judicial Power and the Media: The Problem of Interaction]. Sudebnyi byulleten, 1. 